\title{
A Change of a Consonant Status: the Bedouinisation of the [j] Sound in the Speech of Kuwaitis: A Case Study
}

\author{
Abdulmohsen A. Dashti \\ The English Department, College of Basic Education, Ardhiya, Kuwait \\ Rahimah S. Akbar \\ The English Department, College of Basic Education, Ardhiya, Kuwait \\ Hanan A. Taqi (Corresponding author) \\ The English Department, College of Basic Education, Ardhiya, Kuwait \\ E-mail: hanan.taqi@gmail.com
}

Received: 19-01- 2015

Accepted: 29-03- 2015

Advance Access Published: April 2015

Published: 01-09- 2015

doi:10.7575/aiac.ijalel.v.4n.5p.104

URL: http://dx.doi.org/10.7575/aiac.ijalel.v.4n.5p.104

\begin{abstract}
In light of sociolinguist phonological change, the following study investigates the [j] sound in the speech of Kuwaitis as the predominant form and characterizes the sedentary population which is made up of both the indigenous and nonindigenous group; while [d] is the realisation of the Bedouins who are also a part of the indigenous population. Although [d] is the classical variant, it has, for some time, been regarded by Kuwaitis as the stigmatized form and the [j] as the one that carries prestige. This study examines the change of status of [j] and [d] in the speech of Kuwaitis. The main hypothesis is that [j] no longer carries prestige. To test this hypothesis, 40 Kuwaitis of different gender, ages, educational background, and social networks were spontaneously chosen to be interviewed. Their speech was phonetically transcribed and accordingly was quantitatively and qualitatively analyzed. Results indicate that the [j] variant is undergoing change of status and that the social parameters and the significant political and social changes, that Kuwait has undergone recently, have triggered this linguistic shift.
\end{abstract}

Keywords: Arabic Phonology, Sociolinguistics, Kuwaiti variable, language

\section{Introduction}

Phonological variation is often studied from a sociolinguistic point of view, i.e., by examining the use of variants as a function of external factors such as, sex, age, style, register, and social class (Antilla, 2003). There is a growing awareness that a fruitful cooperation between the diachronic (change of studies over time) and synchronic (limits study to a certain time) study of language variation and change and work in phonological theory is both possible and desirable. The study of language variation and change would benefit from this kind of cooperation on the conceptual and theoretical levels as it enables linguists identify change and reasons behind change. Phonological theory may well profit from a greater use of what is commonly called external evidence (Henskins et al, 1997). The concept of external evidence as a reflection of acquisition patterns, languages comparison, and - in the case of this study- dialectal differences (Zwicky, 1980:598).

Contact between various Arabic vernaculars particularly in the cities and studies of dialect contact (e.g., Salem, 2013; Taqi, 2010; Henkin, 2010; Hoffman, 2008; Al-wer 2007; 2002; Trudgill, \& Kerswill, 2005); have always attracted the interest of sociolinguists who are trying to seek answers as to how and why mutually intelligible linguistic varieties may influence one another when they come into contact, and more importantly the linguistic outcomes of such contact.

Kuwaiti Arabic has been the focus of many researches interested in variation (Dashti, 1998, Taqi, 2010 Dashti \& Dashti 2015 among others). The socio-ethnic diversity in a very small country such as Kuwait, makes it one of the most interesting socio-phonetic places to investigate. In addition, rapid political and social changes influence the rapid phonological changes in terms of what could be considered prestigious and what could not be in the Kuwaiti dialect.

This study investigates the variables [j] and [d] in the context of Kuwaiti Arabic. At first, a review of the literature associated with phonological variation, and especially Kuwaiti Arabic variation will be presented. After stating the research questions, the authors will state the methodology utilized to conduct the study. This will be followed by the results, which will be analyzed in detail in connection with the literature review in the discussion section. Finally, a brief conclusion will provide a clear statement of results and future anticipated studies related to the research. 


\subsection{People of Kuwait}

The capital and original settlement, Kuwait city, is small in both area and population. Most of the country's people live in this city's suburbs and a few outlying towns. Even most of Kuwait's Bedouin--Arabs who are traditionally nomadic-have settled into permanent residences in the districts outside the capital. Thus, virtually the entire population is urban. Kuwaitis often refer to "inner" Kuwait with its more liberal and cosmopolitan atmosphere and "outer" Kuwait, farther from the central city, where conservative Bedouin and tribal influences are stronger. It is not a secret to say that the population of Kuwait is, socially, divided into two main groups, that is, Bedouins and Sedentary. Kuwaitis may be easily recognized by their last names as to which tribe or sect they belong to. Phonological variations in the speech of inner city Kuwaitis and outer city Kuwaitis are recognized by all Kuwaitis.

\subsection{The variable (ds)}

All over the Arabic speaking communities the (ds) variable has a remarkable number of variants:

1. [d]], the classical Arabic variant identified as a voiced palate-alveolar affricate. It has also found in most natively spoken varieties.

2. [j] A variant popular in Eastern Arabian dialects identified as a voices palatal glide.

3. [g] A variant of colloquial Egyptian Arabic and some Eastern Arabian dialects identified as a voiced velar stop.

4. [3] A variant used in urban dialects of the Levant identified as voiced palate-alveolar fricative.

5. [gj] A voiced velar stop followed by voiced palatal glide.

Kuwaiti Arabic has the following variants of the variable (d):

[d子] voiced palate-alveolar affricate

[j] voiced palatal glide.

\subsection{Rational of the study}

Sociolinguists are always interested in the change of the use of variants of a given phonological variable. The Kuwaiti variant [d] of the variable (d), though it is the classical variant, has long been regarded by Kuwaitis as the stigmatized form and the [j] as the one that carries prestige. This is mainly due to the fact that Classical Arabic (CA hereafter) is not the spoken variety in Kuwait. A number of studies have studied the notion of diglossia in Kuwait where [j] and [d 3 ] are in complementary distribution, for example (Dashti \& Dashti, 2015; Al-qenaie, 2011; Taqi, 2010; Alrabaa, 1986), yet, diglossia is beyond the scope of this study. As the amount of use of the [d] variant fluctuates according to social and political influences, this study was initiated by the major social and political changes Kuwait has seen lately. Thus, there might be a change of status in the use of either variants [j] and [d]]. Investigation of such a linguistic change could point to a fundamental geopolitical shift of power amongst the competing Bedouins and Sedentary social groups in the country.

\section{Theoretical Framework and Literature review}

Ingham (1982) claims that in Kuwait and also in the other Gulf States [j] is the predominant form and characterizes the sedentary population which is made up of both the indigenous and non-indigenous group while [d] $]$ is the pronunciation of the Bedouins who are also a part of the indigenous population. Holes (1995) questioned what Ingham (1982:32) referred to as the "multivalency" of dialectical features. The traditional dialectical approach was based on recordings that manifested variation between [j] and [d]]; this attempt at recording such variation was with no attempt at explaining the social values behind the choice of a certain variable rather than the other in any particular Gulf country. He (ibid) adds that in the absence of any research methodology aimed at discovering which type of speaker says what, to whom, when, and ultimately why, a concrete conclusion could not be reached. Studies of the (dz) variable in the Gulf suggest that this variable is greatly involved in linguistic change (Holes, 1980, 1983a, 1983b, 1987, 1995; Johnstone, 1963, 1965, 1967), and especially in Kuwait (Al-Saba'n 1983).

Foulkes and Docherty (2007) illustrated several social parameters that are frequently used in phonological variation studies, namely geographical area, social class and social network, age, sex and gender, race and ethnicity. They investigated the intervocalic/t/-glottalling in two different speaking styles (formal and casual) in Cambridge RP to illustrate how social characteristics influencespeakers' phonological realisation.Abdeljawad \& Abdeljawad (2013:10) "stated that within the same community, different groups of people go through various, economic, political and cultural processes resulting in competing patterns which may lead to inconsistencies in the application of variation". For example, "the Bedouin varieties may be seen as the norm in some communities because they are associated with dominant and powerful groups in places such as Jordan and the Gulf region" (Habib" 2011; Sulieman 2004). Moreover, urbanization, one of the socioeconomic processes, is usually faster among certain social groups than others. This creates a situation whereby in the same household three different patterns may coexist: the parents' patterns, which usually preserve the original domestic forms; female patterns, "which adopt the urban features , and male patterns, which retain the dominant Bedouin features (Habib 2010; Amara 2005;)..

Besides age and gender, social network, too, is an important sociolinguistic parameter in language variation scenarios (Borgati, \& Halgin, 2011; Hajji \& Embarki, 2008). Social network, which was identified by Labov (1972), Milroy (1980) and Milroy and Gordon (2002), focused on the differences between "dense" network and "loose" network. . L. 
Milroy (1980) states that the social network concept investigates the kind of density of relationship which an individual has within the community. A link between two individuals, for example, will be uniplex if they are related in one capacity, such as doctor/patient. On the other hand, the link is multiplex if the ties are in more than one capacity, e.g. friends, neighbors. Density refers to the actual number of links that could exist between all the members of an individual's social network. This study reflects multiplex relationships, where family ties, friendships and neighbors are main areas of investigation.

It is worthwhile shedding light on power and structure of Arab countries. Within Arab countries, some national groups in addition to social, ethnic, and tribal groups usually entertain more political, economic, or tribal power than others which eventually offers their varieties a high status in these countries (Abdeljawad \& Abdeljawad 2013; Taqi 2010; Bassiouney 2009). Holes (1995) in the context of Bahrain, associates these varieties with the royal family. More importantly, speakers tend to accommodate their speech to the politically dominant group variety to assimilate. Phillipson (1992) refers to the dominant group as the "core" group, and to the less dominant as the "periphery" group.

Acosta-Martinez's (2014) examined the phonological process of semi-vocalization in which liquid segments (i.e. /l, r/) become a palatal glide [j] in coda position; it looked at both intra and extra linguistic factors impact on variation patterns of language use among speakers from rural communities of the Dominican Republic. The study, mainly examined the density and multiplexity relationships of speakers network to determine whether they could predict speakers' linguistic behavior. Research suggest that speakers integrated into dense and multiplex networks tend to use more vernacular forms (e.g. semi-vocalization) than speakers integrated into less dense and uniplex networks. Moreover, the study examined the type of ties an individual has with his/her local group; given that individuals with close-knit ties to the local group are found to be more likely to use vernacular forms than those with loose-knit ties (Milroy, 1980), the examination of such ties could predict the linguistic behavior of speakers concerning semivocalization. The results revealed that phonological context, position within the word and stress, as well as speakers' level of education, income and age have an effect on speakers' linguistic choices. In regards to social networks, results showed that an analysis considering their structure and content can only partially explain individual linguistic behavior which suggests that a multidisciplinary approach may be more appropriate to provide a comprehensive account of phonological variation.

Al-Rojaie (2013) investigated the effect of linguistic and social factors (age, gender, and level of education) on the patterns of variation in the affrication of $[\mathrm{t}]$ for $[\mathrm{k}]$ in the stem and suffix in the informal speech of 72 speakers of Qașīmī, a local dialect of Najdi Arabic, spoken in the Qașìm province in central Saudi Arabia. Findings indicate that affrication is significantly favoured in the phonological context of front vowels, particularly the high front ones. Whereas suffix-based affrication is categorically used as [t] , stem affrication is strongly correlated with the age, educational level, and gender of the speaker. In particular, older uneducated speakers from both sexes tend to maintain the use of the local variant $[\mathfrak{g}]$, whereas younger and middle-aged educated speakers, particularly women, increasingly shift toward the use of the supralocal variant $[\mathrm{k}]$. The present findings are suggestive of patterns of variation that are typical in regional-dialect levelling, wherein the supralocal variant(s) associated with the major city dialect is (are) diffusing outward, at the expense of traditional and socially marked variant(s), by speakers of smaller towns' dialects. The substantial socioeconomic changes that Saudi Arabia has undergone in the last half century are suggested to have triggered and accelerated the linguistic shift.

Ismail (2012) investigated young women's and men's speech in the Kingdom of Saudi Arabia during a formal interview. She concluded that women recurrently employed vernacular pronunciation and showed greater use of dialectal Arabic lexicon, often distinctively more localized. Men, on the other hand, approximated more closely to Standard Arabic speech. In her descriptive account of the social meaning conveyed by speakers' code choices in relation to the social indexical effect of each variety. Ismail claimed that in the context of Arab patriarchy, each gender's preference for code choice can be explained by social and cultural norms that impose differential entitlements to the public sphere.

Al-Ali (2010) examined the social impact of gender and educational setting on patterns of variation in the use of $/ \theta /, / d 3$ /and / $/$ / by means of instrumental as well as auditory techniques. 40 male and female participants from two educational backgrounds were interviewed. The results indicated that gender and educational setting differences affect the use of linguistic variants. The results also revealed that men and individuals with high school education have a higher tendency to maintain the use of local variants, whereas women and individuals with university education have a higher tendency to adopt non-local prestigious variants. The paper concluded that male and female speech behaviour depends on social priority. Men are driven by the concept of masculinity and toughness, while women are driven by prestige and softness.

Oladipo Salami (1991) examined the application concept of social network to the process of language usage among Yoruba-speaking city dwellers in Ile-Ife, South-western Nigeria. The study, primarily examined phonetic/phonological variation within Common Spoken Yoruba $(\mathrm{CmSpY})$. Adopting interviews as a methodological approach, the data showed that there is stratification within $\mathrm{CmSpY}$ on the basis of sociodemographic factors, yet, the variable of social network manifests a powerful influence on variation in Yoruba language usage and potential change within $\mathrm{CmSpY}$ in Ile-Ife.

Hussein \& Embarki (2008) investigated the use of Kuwaiti Arabic within a social network made up within a diwaniyya through examining their participants' social network. The idea is to know whether the structure of the diwaniyya can have an influence on the linguistic production of the speakers who gather in the diwaniyya and if they are brought to be influenced by each other. In addition, they perceived the reasons and analyzed how this influence concretely appears 
and if the chief of the diwaniyya, in the center of the social network, exerts an influence on his brothers and his friends, having an effect on their way of speaking. They focused on the sedentary speeches and Bedouin speeches, on their similarities and their differences. They mainly focused on the realization of the two phonemes /qaf/ and/dzim/ according to the social belonging of the speakers and to the pressure exerted within the social network on the choice of phonological variables. Their results showed that several dialectal varieties coexist, based on religious and/or regional or ethnic criteria. The diwaniyya manages to join together all the dialectal varieties which exist in Kuwait and mainly the Bedouin and urban varieties.

In her investigation of the Kuwaiti variation of [j] and [d]], Taqi (2010) investigated the speech of three Kuwaiti generations, descending from two different ethnic backgrounds; namely, Najdi and Ajami. She found that the Najdiand most prestigious at the time- variant [j] was becoming more popular among the youngest generation, while the oldest generation showed very little change towards the prestigious variant. Taqi (ibid) concluded her study by stating that change in the Kuwaiti dialect seems to be constant as the effect of prestige and the change of social status seemed to have great impact on the realizations of certain variants.

\section{Methodology}

This study is meant to investigate the change of the status of the variants of the Kuwaiti variable (d)). The change of status of the variants of the variable (d) will be examined across different social parameters; namely, gender, level of education, social network, neighborhood. Both quantitative and qualitative analysis will be fused. Percentages of the occurrence of the two variables and their variants in the speech of our informants will be quantified. By calculating the frequency index of the variants for the variable under investigation, we will then establish a social structure around findings.

SPSS software was used to calculate all tokens of the (d) variable and its variants produced by each informant. The quantitative method was used to calculate the frequency index of the different variants for the different variants for the variable (d) as shown below:

\begin{tabular}{|l|c|}
\hline $\begin{array}{l}\text { Frequency index of variants } \\
\text { Of }\left(d_{3}\right)\end{array}$ & Total number of occurrences of a particular variant \\
& Total number of occurrences of all variants of (ds) \\
\hline
\end{tabular}

\subsection{Identifying the subjects}

40 informants of different genders, ages, educational backgrounds, and ethnic groups were interviewed. Recorded conversations were used as a technique to obtain spontaneous conversational speech from the informants. During conversations, key topics were specified with no fixed order of the questions, where the recordings did not take the form of a formal structured interview. The recordings were based on general discussion focused on social matters. The overall strategy during the conversations was to ask about broad issues and give the lead as much as possible to informants to freely discuss some of these issues. Traditionally in Kuwaiti social gatherings, men and women are separated. Men have their own gathering domains, and women have also their own. One of the most popular male domains is the Diwaniyah or parlour. The term originally referred to the section of a Bedouin tent where the menfolk and their visitors sat apart from the family. In the old city of Kuwait, it was the reception area where a man received his business colleagues and guests. Today the term refers both to a reception hall and the gathering held in it, and visiting or hosting a Diwaniyah is an indispensable feature of a Kuwaiti man's social life. As a social event, a Diwaniyah takes place in special room or annex, which is usually, a segregated area from the rest of the man's house. Only men are present, and the host's job is to be hospitable and entertain his guests. Interviewing the males was carried out by the first author, while interviewing the female informants was carried out by the second and third authors. A total of five hours for each group were recorded. The data was then transcribed and statistically analyzed. The second step was to formally interview those informants whose speech has shown a change of status of the variable under discussion to seek social explanations.

Table 1, and 2 below shows the distribution of female and male informants successively.

Table 1. Distribution of female informants (1-10, Bedouins; 11-20, Sedentary)

\begin{tabular}{|c|c|c|c|c|c|c|c|}
\hline $\begin{array}{l}\text { Bedouin } \\
\text { informants }\end{array}$ & Age & Education & Neighborhood & $\begin{array}{l}\text { Sedentary } \\
\text { informants }\end{array}$ & Age & Education & Neighborhood \\
\hline 1 & 25 & $\begin{array}{l}\text { University } \\
\text { degree }\end{array}$ & Inner-city & 11 & 27 & $\begin{array}{l}\text { University } \\
\text { degree }\end{array}$ & Inner-city \\
\hline 2 & 32 & $\begin{array}{l}\text { University } \\
\text { degree }\end{array}$ & Outer-city & 12 & 35 & $\begin{array}{l}\text { University } \\
\text { degree }\end{array}$ & Outer-city \\
\hline 3 & 42 & $\mathrm{PhD}$ & Inner-city & 13 & 41 & $\mathrm{PhD}$ & Inner-city \\
\hline 4 & 39 & $\mathrm{PhD}$ & Outer-city & 14 & 54 & $\mathrm{PhD}$ & Inner-city \\
\hline 5 & 34 & $\begin{array}{l}\text { Master's } \\
\text { degree }\end{array}$ & Inner-city & 15 & 60 & $\begin{array}{l}\text { Master's } \\
\text { degree }\end{array}$ & Inner-city \\
\hline
\end{tabular}




\begin{tabular}{llllccll}
\hline $\mathbf{6}$ & 20 & $\begin{array}{l}\text { High } \\
\text { school }\end{array}$ & Inner-city & 16 & 20 & High school & Outer-city \\
$\mathbf{7}$ & 36 & $\begin{array}{l}\text { High } \\
\text { school }\end{array}$ & Outer-city & 17 & 34 & High school & Inner-city \\
$\mathbf{8}$ & 46 & elementary & Inner-city & 18 & 47 & High school & Outer-city \\
$\mathbf{9}$ & 57 & Illiterate & Outer-city & 19 & 69 & elementary & Inner-city \\
$\mathbf{1 0}$ & 65 & Illiterate & Inner-city & 20 & 76 & elementary & Inner-city \\
\hline
\end{tabular}

Table 2. Distribution of male informants (1-10, Bedouins; 11-20, Sedentary)

\begin{tabular}{|c|c|c|c|c|c|c|c|}
\hline $\begin{array}{l}\text { Bedouin } \\
\text { informants }\end{array}$ & Age & Education & Neighborhood & $\begin{array}{l}\text { Sedentary } \\
\text { informants }\end{array}$ & Age & Education & Neighborhood \\
\hline 1 & 22 & $\begin{array}{l}\text { University } \\
\text { degree }\end{array}$ & Outer-city & 11 & 25 & $\begin{array}{l}\text { University } \\
\text { degree }\end{array}$ & Inner-city \\
\hline 2 & 36 & $\begin{array}{l}\text { 2-years } \\
\text { college } \\
\text { degree }\end{array}$ & Outer-city & 12 & 26 & $\begin{array}{l}\text { University } \\
\text { degree }\end{array}$ & Inner-city \\
\hline 3 & 46 & $\mathrm{PhD}$ & Inner-city & 13 & 40 & PhD & Inner-city \\
\hline 4 & 55 & $\mathrm{PhD}$ & Inner-city & 14 & 49 & $\begin{array}{l}\text { Master's } \\
\text { degree }\end{array}$ & Inner-city \\
\hline 5 & 63 & Elementary & Outer-city & 15 & 64 & $\begin{array}{l}\text { University } \\
\text { degree }\end{array}$ & Inner-city \\
\hline 6 & 19 & $\begin{array}{l}\text { High } \\
\text { school }\end{array}$ & Inner-city & 16 & 27 & $\begin{array}{l}\text { Community } \\
\text { College } \\
\text { degree }\end{array}$ & Outer city \\
\hline 7 & 39 & $\begin{array}{l}\text { High } \\
\text { school }\end{array}$ & Outer-city & 17 & 31 & $\begin{array}{l}\text { Community } \\
\text { College } \\
\text { degree }\end{array}$ & Outer-city \\
\hline 8 & 48 & Elementary & Inner-city & 18 & 47 & $\begin{array}{l}\text { University } \\
\text { degree }\end{array}$ & Inner-city \\
\hline 9 & 59 & Illiterate & Outer-city & 19 & 73 & Elementary & Inner-city \\
\hline 10 & 67 & Illiterate & Outer-city & 20 & 80 & Illiterate & Inner-city \\
\hline
\end{tabular}

\subsection{Research questions}

This paper attempts to answer the following questions:

1. Are Kuwait variants [j] and [d] undergoing change of status?

2. Is there any significant differences in the occurrence of [j] and [d] in the speech of Kuwaitis as far as gender, social network, level of education, and neighborhood are concerned?

\section{Analysis \& Discussion}

It is essential to mention that all words (those borrowed from CA in particular) in which the variable under discussion does not vary were excluded. For example/djarida/ 'a newspaper', /mudztamaS/ 'society', /dgama:1/ 'beauty' were exempted simply because (d) is always [d]]. Tables 3 and 4 below show the different realizations of the variants of the (d) variable in the speech of female and male informants consecutively.

Table 3. The realization of the $[\mathrm{j}]$ and the $[\mathrm{d}]$ ] variants of the (dg) variable in the speech of female informants

\begin{tabular}{llllll}
\hline $\begin{array}{l}\text { Bedouin } \\
\text { informants }\end{array}$ & {$[\mathbf{j}]$} & [d] & $\begin{array}{l}\text { Sedentary } \\
\text { informants }\end{array}$ & {$[\mathbf{j}]$} & {$[\mathbf{d}]$} \\
\hline $\mathbf{1}$ & $2 \%$ & $96 \%$ & 11 & $82.1 \%$ & $17.8 \%$ \\
$\mathbf{2}$ & $0 \%$ & $100 \%$ & 12 & $96.6 \%$ & $3.3 \%$ \\
$\mathbf{3}$ & $2.7 \%$ & $97.2 \%$ & 13 & $90.5 \%$ & $10.4 \%$ \\
$\mathbf{4}$ & $0 \%$ & $100 \%$ & 14 & $91.6 \%$ & $8.3 \%$ \\
$\mathbf{5}$ & $6.6 \%$ & $93.7 \%$ & 15 & $93.8 \%$ & $6.1 \%$ \\
$\mathbf{6}$ & $4.3 \%$ & $95.6 \%$ & 16 & $52.3 \%$ & $47.6 \%$ \\
$\mathbf{7}$ & $2 \%$ & $97.9 \%$ & 17 & $30.3 \%$ & $69.8 \%$ \\
$\mathbf{8}$ & $5.9 \%$ & $94 \%$ & 18 & $41 \%$ & $58.9 \%$ \\
\hline
\end{tabular}




\begin{tabular}{llllll}
\hline $\mathbf{9}$ & $0 \%$ & $100 \%$ & 19 & $93.3 \%$ & $6.6 \%$ \\
$\mathbf{1 0}$ & $0 \%$ & $100 \%$ & 20 & $100 \%$ & $0 \%$ \\
\hline
\end{tabular}

Table 4. The realization of the [j] and the [d] variants of the

(d) variable in the speech of male informants

\begin{tabular}{llllll}
\hline $\begin{array}{l}\text { Bedouin } \\
\text { informants }\end{array}$ & [j] & [d]l & $\begin{array}{l}\text { Sedentary } \\
\text { informants }\end{array}$ & [j] & [d] \\
\hline $\mathbf{1}$ & $1.6 \%$ & $98.3 \%$ & 11 & $56.1 \%$ & $43.9 \%$ \\
$\mathbf{2}$ & $1.8 \%$ & $98.1 \%$ & 12 & $60.7 \%$ & $39.4 \%$ \\
$\mathbf{3}$ & $0 \%$ & $100 \%$ & 13 & $45.3 \%$ & $54.6 \%$ \\
$\mathbf{4}$ & $4.1 \%$ & $95.8 \%$ & 14 & $37.2 \%$ & $62.7 \%$ \\
$\mathbf{5}$ & $0 \%$ & $100 \%$ & 15 & $86.2 \%$ & $13.7 \%$ \\
$\mathbf{6}$ & $4.6 \%$ & $95.3 \%$ & 16 & $13.9 \%$ & $86 \%$ \\
$\mathbf{7}$ & $1.5 \%$ & $98.4 \%$ & 17 & $15.5 \%$ & $84.4 \%$ \\
$\mathbf{8}$ & $3.1 \%$ & $96.8 \%$ & 18 & $30.2 \%$ & $69.7 \%$ \\
$\mathbf{9}$ & $0 \%$ & $100 \%$ & 19 & $85.2 \%$ & 14.7 \\
$\mathbf{1 0}$ & $0 \%$ & $100 \%$ & 20 & $94 \%$ & $5.9 \%$ \\
\hline
\end{tabular}

Table 3 above clearly shows that the occurrence of the variant [dz] in the speech of the Bedouin females is significantly higher than that of the sedentary females, with no change of the status of the (dz). On the other hand, the occurrence of the [j] variant in the speech of the sedentary females is significantly higher than that of the Bedouin females except for informants 16,17 , and 18. In order to account for the change of status in their speech, we looked closely into their social network links of which we may summarize as follow:

Informant 16: has moved to live outer city since she was 10 years old. She is more exposed to the [d] variant as her strong social ties with her school friends (which is a significant norm enforcement mechanism) gives her a greater exposure and familiarity to use the Bedouin variant. This comprises with Milroy's (1980) views reflected in the literature review above. Similarly, her family ties with relatives and inner city friends are characterized as weak ties, and through which linguistic change tends to be more predictable. Hence, the variable (dz) in the speech of informant 17 is more likely undergoing change as a result. This, too, comprises with views stated by Trudgill (1986).

Informant 17: is a sedentary female who is married to a Bedouin. Her husband is a $\mathrm{PhD}$ holder who moved to live inner city 8 years ago. She got married to him when she was 21 years old and went to live with him in the USA while he was doing his graduate studies. There, they lived in a neighborhood close to other Kuwaiti families. Most of these families were Bedouins. Similarly, these families consisted of male Bedouins who were university students and accompanied by their Bedouin wives. During the five years that she accompanied her husband in the USA, she had strong ties with these Bedouin females. It is unlikely for Bedouin husbands to let their wives mix with their male friends. It is a norm in the Bedouin tradition that whenever there is a family social gathering, females usually gather in a separate room to that of the men. Hence, due to the fact that she and all those female Bedouins were only housewives, they spent most of their time together whenever their husbands leave to school. Their relationship was one of a multiplex. In Kuwait, despite the fact that she and her husband live inner city, she still keeps strong ties with her same female friends who came back from the USA. In addition, she has also strong ties with her husband's family. It is worthwhile mentioning that her husband has six other brothers five of which are married, and none of them is married to a sedentary. Ties with her own family are weak since she has no sisters and only one brother. Moreover, she claims that she probably meets with her cousins only once a year. In addition, because she left to the states when she was only 21, she has no sedentary friends in Kuwait. This social network clearly explains the somewhat high percentage of the occurrence of the [d] variant in her speech.

Informant 18: is married to a Bedouin and moved to live with him outer city. She has been married for 22 years. Since her marriage, she moved to live in her husband's family house. Actually, she and her husband are cousins, yet, her parents lived inner city all their lives. She was born inner city and she went to schools where all her friends were sedentary. She claims that she has rarely heard their parents saying [d] instead of [j]. This might be justified in the light of the prestige notion. We have mentioned above that the [j] has always carried prestige. Her brothers and sisters, she claims have never used [d] either. Examining our informant's social network, and taking into consideration her age (49) which is considered an old age to Kuwaiti females, we see that she has strong ties with her mother-in-law and her husbands' elder sisters. Again, she is a house wife and consequently she spends most of her time with her husband's family. She claims that her parents' family used to have a weekly social gathering and she used to go and visit every fortnight. But, since the death of her mother (11 years ago) and her father ( 7 years ago) she rarely visited her sisters and brothers. Through these week ties with her parents' family and strong ties with her husband's family that the change of 
the use of the variable under discussion occurs. Moreover, the above analysis clearly shows that social network is a salient parameter in linguistic change.

Moving to our male informants, we see a completely phonological variation pattern. The statistical analysis shows that the [d] variant does appear in the speech of most of the sedentary informants, namely, 11, 12, 13, 14, 16, 17, and 18, side by side with the [j] variant. However, similar to the female Bedouin informants, our male Bedouin informants kept their [d] variant consistently unchanged, while change has occurred in the speech of our sedentary informants.

It is worth mentioning at this point that informants 11 and 12 are close friends. They both live inner city with their families. They are still single. Both of them got their bachelor degrees from Britain. Informant 11 got his bachelor degree in petroleum engineering, and informant 12 got his bachelor degree in mechanical engineering. They met each other in Britain as they were both studying in the same university. Informant 11 claims that during his study in middle school and high school in Kuwait, all his friends were Bedouins. Moreover, he claims that during his study period in Britain, all his friends were Bedouins as well. Informant 12, on the other hand, claims that his friends in the middle school and high school were a mixture of Sedentary and Bedouins, yet his friends in his neighborhood in Kuwait were mostly Bedouins. Now that both are back to Kuwait, they both work for a petroleum company (KOC) where again all their colleagues are Bedouins too. During their spare time they either socialize with their friends in a diwaniya that is annexed to one of their friend's family house, or they meet with their friends in a number of international cafes such as Starbucks, Costa, Second Cup, Nestle, and the like, where the younger generation use as alternatives to diwaniyas. In addition, during holidays they and their Bedouin friends travel out of town. As typical Kuwaiti single males, they rarely spend time with their family members. Yet again, the analysis above show that the social network of informants 11 and 12 is one of a multiplex with their friends. This clearly explains the occurrence of the [d] variant in their speech of informant 11 (43.9\%) and in the speech of informant 12 (39.4\%).

Informant 13 and 14: are both married with children have got postgraduate degrees and whose social network is stronger with sedentary relatives and friends than Bedouin friends. The occurrence of the [d]] variant in their speech (54.6\%), (62.7\%) successively was unexpected. In a follow up interview, the two informants were directly asked about their excessive deployments of [d] variant in their speech. Convincingly, they related to the fact that they hold higher degrees (Masters, and PhD) which are considered respectful titles in Kuwait. As a result, they further explained, they, most of the time, monitor their speech during social gatherings, where they accentuate their use of [d] variant as it indicates highly educated ranking. They also claimed that whenever they listen to a person using the [j] variant, they downgrade him. Interestingly, they claim that they perceive the [d]] variant as holding a more masculine connotation when compared to the more feminine [j]. This beautifully corresponds to with what the highly educated female informants stated. One of the female informants wondered if there were Kuwaiti women who would say [d] instead of [j]: "wow, she said, this is peculiar... I think they would sound like men".

Informants 16 and 17 were both born outer city. All their school friends, teachers, and neighborhood friends are Bedouins. They claim that they and their brothers and sisters talk like Bedouins although they realize that they are not Bedouin. Despite the fact that the [j] variant, they claim, is their mother tongue and that it does appear in their parents' speech when they talk to them, yet, when their parents are with neighborhood friends, they mostly employ the [d] variant. Moreover, they claim that whenever they visit their cousins who live inner city, though they rarely do, they and their brothers and sisters always feel that their cousins sound funny using the [j] variant. They add that they don't like it when their cousins come and visit them in their house. They always feel embarrassed, they say. This is because their friends in the neighborhood seize the opportunity to ridicule them because of the [j] variant in their speech. The density and multiplexity in informant 16's and 17's social network shown in the above description may well account for high percentage $(86 \%),(84.4 \%)$ successively, of the occurrence of the [d] variant in their speech.

Informant 18: is 47 male sedentary who is married to a Bedouin female. The couple has been married for 23 years. Their marriage, he claims was against his parents' wish as they wanted him to marry one of his cousin. It is worthwhile mentioning that getting married from different sects is hardly acceptable by most Kuwaiti families, and definitely, 23 years ago it was not acceptable. On the other hand, his wife's family, especially, her parents, was not against their marriage at all. He claims that he runs his own business. It started very small but now his company has a number of branches in Saudi Arabia and Dubai. He frequently flies to Saudi Arabia to look after his business. His brother-in-law (his wife's brother) takes care of the business in Dubai. Consequently, he meets with people from Saudi Arabia very often, either in Kuwait or in Saudi Arabia. We know from literature (e.g., Al-Rojaie 2013; Hajji \& Embarki, 2008; Johnstone $1963,1965,1967)$ that the [d] variant is mainly used by people from Saudi Arabia. So, his contact with them actually was one reason for the occurrence of the [d] variable in his speech. Moreover, his contact with his family members, he claims, is still very weak. However, he still keeps good relations with his sedentary friends.

The discussion above clearly shows that the variants[j] and [d] are undergoing change of status. The statistical analysis indicates that there are differences in the occurrence of the variants of the [j] and [d] in the speech of Kuwaitis with regard to social parameters, namely, gender, level of education, social network, and neighborhood. As far as gender is concerned, the analysis shows that the change of status in the speech of our male informants is statistically higher than that of females. The [j] variant occurs more often in our female informants' speech than that in the speech of our male informants. We have mentioned that the [d] variant is the high variant and supposed to be more prestigious. Moreover, literature, e.g., (Taqi, 2010; Al-Wer 2007, 2002; Holes 1995; ) indicates that women tend to use prestige forms more 
than men do. Our findings seem to contradict with previous research. Further research need to be carried out to verify our findings.

As to level of education, the statistical analysis shows that the occurrence of the [d] variant among our female informants is higher in the speech of the less educated than that of the more educated informants. On the contrary, and among our male informants, the statistical analysis shows that the occurrence of the [d] variant is higher in the speech of the more educated informants than that of the less educated informants.

The qualitative analysis, on the other hand shows that social network of both our male and female informants together with neighborhood are salient parameters in the change of the status of the phonological variable under discussion.

\section{Conclusion}

This paper revolved around phonological variation in Kuwait. It examined the change in status of both the variants [d 3 ] and [j] as variants of the variable (dz) in the speech of Kuwaitis. A sociolinguistic investigation was drawn to see if the social parameters of gender, level of education, social network, and neighborhood could account for the change of status of the phonological variable under discussion. Results indicate that the [j] variant is undergoing change of status and that the social parameters under discussion well account for such a change. The researchers believe that the significant political and social changes that Kuwait has undergone recently have enhanced the linguistic shift. Therefore, future phonological status of the variants mentioned would be possible as it seems to depend heavily on the social and political dimensions of the Kuwaiti community.

The study's findings imply a strong geopolitical shift of the powers that used to be associated with Sedentary Kuwaitis into Bedouin Kuwaitis. The study may therefore indicate an intensive socioeconomic and political turnover of the two competing social sects in the country, whereby Bedouins are more likely becoming the core group, and Sedentary Kuwaitis might be losing their power and becoming the periphery group. A follow up study on the same matter may look into the macro analysis that might have led to such a strong shift, particularly when someone considers the political recent instability of the country.

\section{References}

Abdeljawad, H. \& Abdeljawad, R. (2013) Sociolinguistic Variation in Arabic: A New Theoretical Approach. Dialectologia, 11, 1-28.

Acosta-Martinez, Junice A. (2014) Phonological Variation in Cibaeño Spanish: Social Networks as Potential Predictors of Semi-Vocalization. Unpublished PhD Dissertation, University of Illinois at Chicago, 2014.

Al- Ali, M. (2010) An Experimental Social Study of Language Variation in a Jordanian Arab. The Buckingham Journal of Language and Linguistics Volume 3 pp 207-230

Alrabaa, S. (1986) Diglossia in the classroom: the Arabic case. Anthropological linguistics, 28(1), Spring 1986

Al-Rojaie, Y. (2013) Regional dialect levelling in Najdi Arabic: The case of the deaffrication of [k] in the Qașimi dialect. Language Variation and Change, Vol. 25, Issue 1, March 2013, pp 43-63. http://dx.doi.org/10.1017/S0954394512000245

Al-Saba'n, L. (1983) Tatawur il lahja il Kuwaitiya. Publisher: Sherikat al ribei'an l'innasher wa' tawzee': Kuwait.

Al-qenaie, S. D. (2011) Kuwaiti Arabic: A Socio-Phonological Perspective. Unpublished PhD thesis, Durham University.

Al-Wer, E. (2007). The Formation of the Dialect of Amman: From Chaos to Order. Arabic in the City, ed. By Catherine Miller, Enam Al-Wer, Dominique Caubet, and Janet, C, E, Watson. Routledge.

(2002). Jordanian and Palestinian Dialects in Contact: vowel raising in Amman. Language change: the interplayof internal, external and extra-linguistic factor, ed. By M. Johns and E. Esch. Berlin: Mouton de Gruyter.

Amara. M. (2005) “Language, Migration, and Urbanisation: The Case of Bethlehem”. Linguistics: 43(5) 883-901. http://dx.doi.org/10.1515/ling.2005.43.5.883

Antilla, A. (2003) Variation and Phonological Theory. In The Handbook of Language Variation and Change. Edited by: J. K. Chambers, Peter Trudgill and Natalie Schilling-Estes, 2003.

Bassiouney, R. (2009) Arabic Linguistics. Edinburgh: Edinburgh University Press.

Borgati, S. P., \& Halgin, D. S. (2011). On network theory. Organisation Science, 22, 1168-1181. http://dx.doi.org/10.1287/orsc.1100.0641

Dashti, A. \& Dashti, F. (2015). Is Kuwait TV diglossic? A sociolinguistic Investigation. . European Scientific Journal, Vol. 11, No, 1-3, January, 2015.

Foulkes and Docherty (2007) "Phonological Variation in England, In David Britain (ed.) Language in the British Isles, Cambridge: Cambridge University Press, 52-74. http://dx.doi.org/10.1017/CBO9780511620782.006

Habib ,R (2011a) "Meaningful variation and bidirectional change in rural child and adolescent language", University of Pensylvania, working papers in Linguistics, 17(2), 81-90 
Habib ,R (2010) “Rural Migration and Language Language Variation in Hims, Syria”. SKY Journal of Linguistics, 23, 61-99

Hajji, h. 7 Embarki,. M (2008) Urban and Bedouin features : A pilot study of phonological variation within a _diwaniyya_in Kuwait. Sociolinguistics Symposium: icro and macro connections, 3-5, April, 2008, Amestrdam.

Henkin, R. (2010). Negev Arabic:Dialectical, sociolinguistic, and Stylistic Variation. Harrassowitz Verlag.

Hinskens, F., Van Haut, R. \& Wetzels, W. (1997). "Balancing data and theory in the study of phonological variation". In Frans Hinskens et al. (eds.) Variation, Change, and Phonological Theory. Amestrdam:John Benjamins, 1-33. http://dx.doi.org/10.1075/cilt.146.03hin

Hoffman, K. (2008) We Share Walls: Language, Land and Gender in Berber Morocco. Blackwell studies in discourse and culture 2. Malden, MA: Blackwell Pub.

Holes, C (1980) Phonological Variation in Bahraini Arabic: [d] and [j] allophones of (d). Zeitschrift Fur Arabische Linguistik No. 72-89.

(1983a) Bahraini Dialects: 'Sectarian differences and the sedentary/nomadic split'. ZAL 10-38.

(1983b) 'Patterns of Communal Language Variation in Bahrain. LS 12:4: 433-57.

(1987) Language variation and change in a modernizing Arab state. The case of Bahrain. London and New York: Kegan Paul International.

Holes, C (1995) Community, Dialect Urbanisation in the Arabic- Speaking Middle East. Bulletin of the School of Oriental and African Studies, University of London 58. pp. 270-287.

Ismail, M. A. (2012) Sociocultural Identity and Arab Women's and Men's Code-Choice in the Context of Patriarchy. Anthropological Linguistics Vol.54, N0. 3, Fall 2012, pp. 261-279

Johnstone, T. M. (1963) 'The Affrication of 'KAF' and 'GAF' in the dialects of Peninsular Arabia'. Journal of Semetic Studies, Vol, 8, No, 2:210-226. http://dx.doi.org/10.1093/jss/8.2.210

Johnstone, T. M. (1965) 'The Sound Change j/y in the Arabic dialects of Peninsular Arabia'. Bulletin of the school of Oriental and African studies 28, 2, 233-241. http://dx.doi.org/10.1017/S0041977X0007508X

Johnstone, T. M. (1967) Eastern Arabian Dia,ect Studies. Oxford University Press.

Labov, W. (1972) Sociolinguistic Patterns. Philadelphia: Pennsylvania University Press.

Milroy, L. Language and Social Network. Oxford: Blackwell.

Milroy, L. \& M. Gordon (2003). Sociolinguistics: Method and Interpretation. Oxford: Blackwell. http://dx.doi.org/10.1002/9780470758359

Oladipo Salami (1991). Diffusion and focusing: Phonological variation and social networks In Ile-Ife, Nigeria. Language in Society, 20, pp 217-245. http://dx.doi.org/10.1017/S0047404500016286

Phillipson, R. (1992) Linguistic Imperialism. Oxford: Oxford University Press.

Salem, A. (2013) Linguistic Features of Pidgin Arabic in Kuwait. English Language Teaching; Vol. 6, No. 5; 2013

Sulieman, Y. (2004) A war of Words: Language and Conflict in the Middle East. Cambridge: Cambridge University Press. http://dx.doi.org/10.1017/CBO9780511819926

Taqi, H. (2010). Two Ethnicities, Three Generations: Phonological Variation and Change in Kuwait. Unpublished Ph.D. Thesis, Newcastle University.

Trudgill, P. \& Kerswill. P. (2005). The Birth of New Dialects. Dialect Change: Convergence and Divergence in European Languages. Cambridge University Press.

Zwicky, A. M. (1980) Internal and External Evidence in Linguistics. Proceedings of the Biennial Meeting of the Philosophy of Science Association, The University of Chicago Press, Vol. 2, pp. 598-604. 